\title{
Biosorption of Fe(II) and Mn(II) Ions from Aqueous Solution by Rice Husk Ash
}

\author{
Ying Zhang, Jiaying Zhao, Zhao Jiang, Dexin Shan, and Yan Lu \\ School of Resource and Environment, Northeast Agricultural University, Harbin 150030, China \\ Correspondence should be addressed to Ying Zhang; zhangyinghr@hotmail.com
}

Received 18 April 2014; Revised 10 May 2014; Accepted 11 May 2014; Published 1 June 2014

Academic Editor: Qaisar Mahmood

Copyright (C) 2014 Ying Zhang et al. This is an open access article distributed under the Creative Commons Attribution License, which permits unrestricted use, distribution, and reproduction in any medium, provided the original work is properly cited.

\begin{abstract}
Rice husk ash (RHA), an agricultural waste, was used as biosorbent for the removal of Iron(II) and Manganese(II) ions from aqueous solutions. The structural and morphological characteristics of RHA and its elemental compositions before and after adsorption of $\mathrm{Fe}(\mathrm{II})$ and $\mathrm{Mn}$ (II) were determined by scanning electron microscopic (SEM) and X-ray fluorescence (XRF) analyses. Batch experiments were carried out to determine the influence of initial $\mathrm{pH}$, contact time, adsorbent dosage, and initial concentration on the removal of $\mathrm{Fe}(\mathrm{II})$ and $\mathrm{Mn}$ (II) ions. Langmuir, Freundlich, and Dubinin-Radushkevich (D-R) models were applied to describe the biosorption isotherm of the metal ions by RHA. The correlation coefficient $\left(R^{2}\right)$ of Langmuir and Freundlich isotherm models equals 0.995 and 0.901 for $\mathrm{Fe}(\mathrm{II}), 0.9862$ and 0.8924 for $\mathrm{Mn}(\mathrm{II})$, respectively, so the Langmuir model fitted the equilibrium data better than the Freundlich isotherm model. The mean free energy values evaluated from the D-R model indicated that the biosorption of $\mathrm{Fe}(\mathrm{II})$ and $\mathrm{Mn}$ (II) onto RHA was physical in nature. Experimental data also showed that the biosorption processes of both metal ions complied with the pseudo-second-order kinetics.
\end{abstract}

\section{Introduction}

Currently, the removal of heavy metal contaminants from aqueous wastewater is one of the most important environmental issues being researched. Once metal ions enter the environment, their chemical form largely determines their potential toxicity [1]. Besides the existence in aquatic ecosystem may cause harmful effects to organisms living in water and heavy metals also accumulate throughout the food chain and may affect the health of human beings [2-4].

Iron and manganese are found in groundwater and present in the form of $\mathrm{Fe}(\mathrm{II})$ and $\mathrm{Mn}$ (II) ions [5]. Fe(II) and $\mathrm{Mn}(\mathrm{II})$ often occur together in groundwater, but the concentration of manganese is found to be usually much lower than the concentration of iron [6]. Water percolating through soil and rock can dissolve minerals containing iron and manganese and hold them in solution [7]. Polluted water may cause taste, odor, color, or turbidity problems. Iron and manganese present in groundwater will cause a severe colour condition. When exposed to air, iron and manganese present in the water body become indissoluble and leave the water with brown-red colour. The problems caused by iron and manganese are not only aesthetic problems, but also indirect health concerns and economic problems [8]. Iron and manganese are apparent in drinking water supplies, especially iron. There are secondary standards set to constrain the emissions of iron and manganese ions. The secondary standard maximum contaminant levels (MCLs) for iron and manganese are $0.3 \mathrm{mg} / \mathrm{L}$ and $0.1 \mathrm{mg} / \mathrm{L}$, respectively [9]. Therefore, it becomes necessary to remove these heavy metals from wastewaters by an appropriate treatment technology before releasing them into the environment [10].

A lot of methods are used to remove heavy metals because of the new and effective separation technologies. The most widely used methods for removing heavy metals from wastewaters include ion exchange [11], chemical precipitation [12], preconcentration [13], reverse osmosis [14], membrane filtration [15], and adsorption biological treatment [16-18]. Most of these methods suffer from some disadvantages such as high operational cost and are not suitable for small-scale industries or do not lead to a satisfactory result. Among these technologies, adsorption is a most common technique for the removal of heavy metal. This process seems to be more user friendly and effective if combined with appropriate 
bioadsorbent and regeneration steps. Activated carbon has been widely applied for removing heavy metals from water and wastewater [19-21]. Recently, the number of researches focused on the use of activated carbon as adsorbents is reducing due to their high capital and operational costs. Therefore, more interests have recently arisen in the investigation of low-cost adsorbents with a good sorption capacity to remove heavy metal ions from wastewater. For the past few decades, more researchers have concentrated on the use of agricultural wastes as adsorbents. Agricultural wastes such as fly ash [22], natural zeolite [23], wheat bran [24], bark and sawdust [25], peanut shells [26], and rice husk [27] have been developed for heavy metals removal from aqueous solution.

Rice husk is a kind of byproduct obtained from the rice mills and usually available in a large quantity of production [28]. Rice husk is mostly used as a fuel and burned in the boiler of various industries to produce steam, thus, conserving both energy and resources. The ash generated after burning the rice husk in the boiler is called rice husk ash (RHA). The RHA was collected from the particulate collection equipment attached upstream to the stack of ricefired boilers. Since RHA is safe and available in plenty, and it has the possibility to function as an adsorbent, the objective of this work was to examine the adsorption characteristics of RHA to adsorb $\mathrm{Fe}(\mathrm{II})$ and $\mathrm{Mn}$ (II) ions from an aqueous solution. The effects of sorption parameters such as $\mathrm{pH}$, contact time, adsorbent dosage, and initial concentration were examined. The equilibrium data were analyzed using Langmuir and Freundlich isotherm models. Kinetic studies were carried out, and the data were analyzed using pseudofirst-order and pseudo-second-order equations.

\section{Experimental}

2.1. Adsorbent Preparation of Highly Active RHA. The RHA was used as biosorbent for the biosorption of $\mathrm{Fe}(\mathrm{II})$ and $\mathrm{Mn}$ (II) ions. Samples of the biomass were collected from Heilongjiang Province, Shangzhi, surrounding rice mill. The sample was dried in an oven at $60^{\circ} \mathrm{C}$ for 3 hours, then put in dryer, and stored for later use.

2.2. Batch Adsorption Studies. Biosorption experiments were carried out by shaking $150 \mathrm{~mL}$ flasks containing $50 \mathrm{~mL}$ of $\mathrm{Fe}(\mathrm{II})$ and $\mathrm{Mn}$ (II) solutions of the desired concentration on a shaker machine at a revolving speed of $130 \mathrm{rpm}$, at $25^{\circ} \mathrm{C}$. The mixture was filtered using an acid-cleaned $0.45 \mu \mathrm{m}$ Millipore filter and the concentration of $\mathrm{Fe}(\mathrm{II})$ and $\mathrm{Mn}$ (II) in the filtrate was determined by atomic absorption spectrometry (Model AA6800, Shimadzu, Japan). Effect of $\mathrm{pH}$ on the adsorption of $\mathrm{Fe}(\mathrm{II})$ and $\mathrm{Mn}$ (II) by RHA was studied from 1.0 to 8.0 . The $\mathrm{pH}$ was adjusted with $0.1 \mathrm{~mol} / \mathrm{L} \mathrm{HCl}$ and $\mathrm{NaOH}$ solutions; a $\mathrm{pH}$ meter (pHS-3C, China) was employed for measuring $\mathrm{pH}$ values in the aqueous phase. The effect of contact time was studied by taking out the samples from the shaker at regular time intervals till equilibrium was reached. The effect of adsorbent dose was studied with different adsorbent doses ranging from 0.2 to $1.5 \mathrm{~g} / 50 \mathrm{~mL}$. The effect of initial concentration was studied from $5 \mathrm{mg} / \mathrm{L}$ to $40 \mathrm{mg} / \mathrm{L}$, and initial solutions with different concentrations of $\mathrm{Fe}(\mathrm{II})$ and $\mathrm{Mn}(\mathrm{II})$ were prepared by proper dilution from stock of $1000 \mathrm{mg} / \mathrm{L} \mathrm{Fe}$ (II) and Mn(II) standards. All experiments were repeated three times, and results presented are consequently the averaged values of replicate tests.

The X-ray fluorescence (XRF) spectrum analysis (Model Axios PW4400, PANalytical) was conducted for the element composition of raw rice husk ash. The surface morphology of rice husk ash was carried out by using a scanning electron microscope (Model S-3400N, HITACHI).

Sorption isotherms were conducted at sorbent dose of $0.5 \mathrm{~g}$ and varying the concentration of $\mathrm{Fe}$ (II) and $\mathrm{Mn}$ (II) from $2 \mathrm{mg} / \mathrm{L}$ to $40 \mathrm{mg} / \mathrm{L}$ in $150 \mathrm{~mL}$ flasks containing $50 \mathrm{~mL} \mathrm{Fe(II)}$ and $\mathrm{Mn}$ (II) solutions. The $\mathrm{pH}$ was adjusted to 5.0 and 6.0, respectively. The mixtures were shaken in an oscillator at $130 \mathrm{rpm}$ for 3 hours and at constant temperature.

The kinetic experiments were performed in continuously stirred flask containing $50 \mathrm{~mL} \mathrm{Fe(II)} \mathrm{and} \mathrm{Mn}$ (II) solutions at concentrations of $20 \mathrm{mg} / \mathrm{L}$ from $5 \mathrm{~min}$ to $90 \mathrm{~min}$ at sorbent dose of $1 \mathrm{~g}$ and $\mathrm{pH} 5$ and 6 , respectively. Likewise, the mixtures were shaken in an oscillator at $130 \mathrm{rpm}$ and at constant temperature. After filtering the mixture, the concentration of $\mathrm{Fe}(\mathrm{II})$ and $\mathrm{Mn}$ (II) in the filtrate was determined by atomic absorption spectrometry.

The percentage removal of $\mathrm{Fe}(\mathrm{II})$ and $\mathrm{Mn}(\mathrm{II})$ ions and equilibrium adsorption amount of $\mathrm{Fe}(\mathrm{II})$ and $\mathrm{Mn}(\mathrm{II}) q_{e}$ ( $\mathrm{mg} / \mathrm{g}$ ) were calculated by using the following equations:

The percentage removal of $\mathrm{Fe}(\mathrm{II})$ and $\mathrm{Mn}(\mathrm{II})$ ions

$$
=\frac{100\left(C_{0}-C_{e}\right)}{C_{0}} .
$$

Adsorption amount of Fe(II) and Mn(II) per gram (g) of adsorbent $(\mathrm{mg} / \mathrm{g})$ is

$$
q_{e}=\frac{\left(C_{0}-C_{e}\right) V}{W},
$$

where $C_{0}$ is the initial concentration of $\mathrm{Fe}(\mathrm{II})$ and $\mathrm{Mn}$ (II) $(\mathrm{mg} / \mathrm{L}), C_{e}$ is the equilibrium concentration of $\mathrm{Fe}(\mathrm{II})$ and $\mathrm{Mn}(\mathrm{II})(\mathrm{mg} / \mathrm{L}), V$ is the volume of the solution (L), and $W$ is the mass of the adsorbent $(\mathrm{g})$.

\section{Results and Discussion}

3.1. Characterization of RHA. In comparing the results of $\mathrm{Fe}(\mathrm{II})$ and $\mathrm{Mn}$ (II) adsorption based on percentages changes, before and after the addition of adsorbent, it can reflect the qualitative transformation and migration mechanisms of the elements and speculate the adsorption mechanism of $\mathrm{Fe}(\mathrm{II})$ and $\mathrm{Mn}$ (II) by RHA. XRF analysis on RHA before and after adsorption of $\mathrm{Fe}(\mathrm{II})$ and $\mathrm{Mn}$ (II) is shown in Table 1. After the RHA adsorbed $\mathrm{Fe}(\mathrm{II})$ and $\mathrm{Mn}(\mathrm{II})$, elements of $\mathrm{Na}$ disappeared, and elements of $\mathrm{Mg}, \mathrm{Al}, \mathrm{K}$, and $\mathrm{Ca}$ decreased significantly. The adsorption process produced some sort of damage on the cytoderm of RHA, leading to the dissolution of intracellular substances; this resulted in ion exchange between $\mathrm{Fe}(\mathrm{II})$ and $\mathrm{Mn}$ (II) ions. Elements of $\mathrm{Cl}$ changed differently in adsorption $\mathrm{Fe}(\mathrm{II})$ and $\mathrm{Mn}$ (II). It indicated that 
TABLE 1: XRF analysis on the RHA before and after adsorption of $\mathrm{Fe}(\mathrm{II})$ and $\mathrm{Mn}(\mathrm{II})$ (\%).

\begin{tabular}{lccc}
\hline Element & $\begin{array}{c}\text { Unloaded } \\
\text { biomass }\end{array}$ & $\begin{array}{c}\text { Fe(II)-loaded } \\
\text { biomass }\end{array}$ & $\begin{array}{c}\text { Mn(II)-loaded } \\
\text { biomass }\end{array}$ \\
\hline $\mathrm{O}$ & 26.650 & 24.530 & 24.183 \\
$\mathrm{Na}$ & 0.040 & - & - \\
$\mathrm{Mg}$ & 0.301 & 0.090 & 0.057 \\
$\mathrm{Al}$ & 0.132 & 0.014 & 0.012 \\
$\mathrm{Si}$ & 29.433 & 27.538 & 27.276 \\
$\mathrm{P}$ & 0.511 & 0.054 & 0.054 \\
$\mathrm{~S}$ & 0.102 & 0.154 & 0.069 \\
$\mathrm{Cl}$ & 0.190 & 0.342 & 0.097 \\
$\mathrm{~K}$ & 2.123 & 0.338 & 0.290 \\
$\mathrm{Ca}$ & 0.942 & 0.061 & 0.048 \\
$\mathrm{Mn}$ & 0.183 & 0.187 & 0.293 \\
$\mathrm{Zn}$ & 0.011 & 0.002 & 0.003 \\
$\mathrm{Fe}$ & - & 0.175 & 0.013 \\
$\mathrm{Cu}$ & - & 0.003 & 0.004 \\
\hline
\end{tabular}

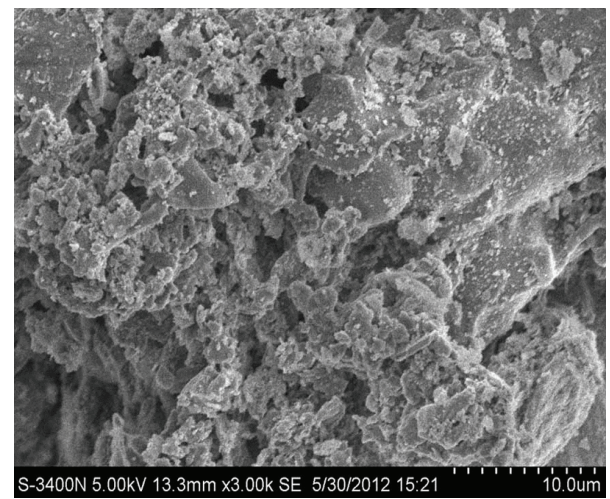

FIgURE 1: Scanning electron micrograph of RHA.

$\mathrm{Cl}$ has produced different effects on $\mathrm{Fe}(\mathrm{II})$ and $\mathrm{Mn}$ (II) adsorption mechanisms. After adsorption of $\mathrm{Fe}(\mathrm{II})$ and $\mathrm{Mn}$ (II) by RHA, the content of $\mathrm{Fe}(\mathrm{II})$ and $\mathrm{Mn}$ (II) in the RHA increased from $0.175 \%$ and $0.183 \%$ to $0.293 \%$, respectively. This result proved that the use of RHA to adsorb Fe(II) and $\mathrm{Mn}$ (II) is feasible.

RHA is a porous material of Trass volcanic ash; the main ingredient is amorphous $\mathrm{SiO}_{2}$, up to $60 \%-97 \%$ content. Scanning electron micrographs of RHA are shown in Figure 1. The surface of RHA is porous, and the surface honeycomb holes can reach micron scale, about 10 microns. The internal structure possesses a number of irregular pieces of layered structure and reticulates. The cross section in the figure shows the irregular holes distribution within the RHA; this may be a result of the combined action of rice husk residue and RHA. The porous structure of RHA has a relatively large specific surface area, and this morphological property is conducive to the uptake of metal ions.

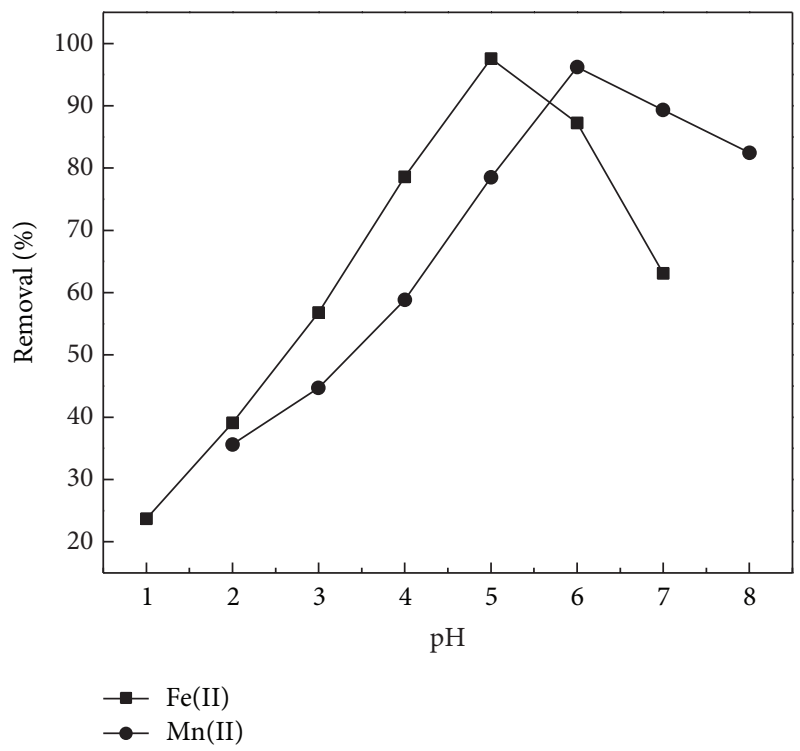

FIGURE 2: Effect of $\mathrm{pH}$ on adsorption of Fe(II) and $\mathrm{Mn}$ (II) by RHA (metal concentration: $20 \mathrm{mg} / \mathrm{L}$; adsorbent dosage: $0.6 \mathrm{~g} / 100 \mathrm{~mL}$.).

3.2. Effect of $p H$. $\mathrm{pH}$ is one of the most important factors affecting biosorption of metal ions. Differences in initial $\mathrm{pH}$ directly affect the competitive ability of hydrogen ions with metal ions for the active sites on the biosorbent surface [29]. The effect of $\mathrm{pH}$ on the biosorption of $\mathrm{Fe}(\mathrm{II})$ and $\mathrm{Mn}$ (II) ions onto RHA was studied at $\mathrm{pH} 1-8$ and the results are presented in Figure 2.

It was observed that the removal amount was increased from 24 to $79 \%$ for $\mathrm{Fe}(\mathrm{II})$ ions and from 36 to $78 \%$ for $\mathrm{Mn}$ (II) ions, as $\mathrm{pH}$ was increased from 1 to 4 and 2 to 5 , respectively. The maximum removal was found to be $98 \%$ for $\mathrm{Fe}(\mathrm{II})$ and $96 \%$ for $\mathrm{Mn}(\mathrm{II})$ ions at $\mathrm{pH} 5$ and 6 , respectively. This phenomenon partly attributed to the fact that when the $\mathrm{pH}$ values increased, biosorbent surfaces were more negatively charged and attracted metal ions with positive charges, thus causing the absorption onto the biosorbent surface [30]. But biosorption efficiency decreased after attaining the maximum biosorption limit. This could be due to the formation of soluble hydroxylated complexes of the metal ions and their ionized nature. Moreover, at higher $\mathrm{pH}$ levels, $\mathrm{Fe}(\mathrm{II})$ and $\mathrm{Mn}(\mathrm{II})$ would be converted into their hydroxide forms and get precipitated. So it could not be concluded that the removal of $\mathrm{Fe}(\mathrm{II})$ and $\mathrm{Mn}$ (II) was due to adsorption or due to precipitation. Above all the following experiments were carried out with pH values of 5 and 6 , respectively.

3.3. Effects of Contact Time. The reaction time is one of the important factors that influence the adsorption process of heavy metals in a medium [31]. Selection of proper adsorption time of heavy metals in wastewater treatment has certain economic benefits. The effect of contact time on the uptake of $\mathrm{Fe}(\mathrm{II})$ and $\mathrm{Mn}$ (II) ions onto RHA was studied and is shown in Figure 3. It was observed that the percentage removal of $\mathrm{Fe}(\mathrm{II})$ and $\mathrm{Mn}$ (II) increased with increase in contact time up to $60 \mathrm{~min}$. After this time there was no considerable 


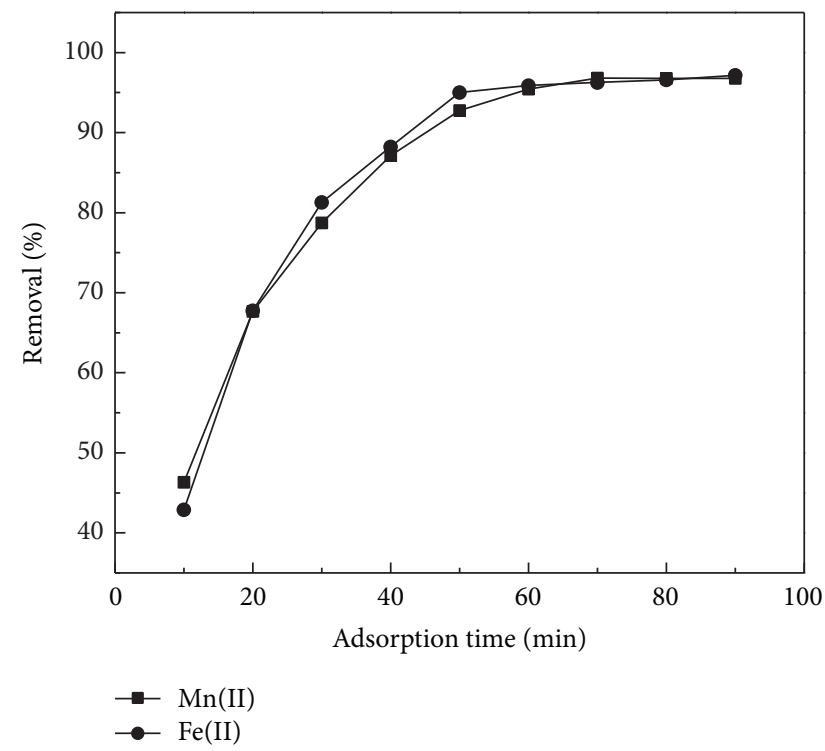

FIGURE 3: Effect of contact time on adsorption of Fe(II) and $\mathrm{Mn}$ (II) by RHA (metal concentration: $20 \mathrm{mg} / \mathrm{L}$; adsorbent dosage: $0.6 \mathrm{~g} / 100 \mathrm{~mL}$; $\mathrm{pH}$ : 5 and 6, resp.).

increase. After $60 \mathrm{~min}$, the biosorption efficiency for $\mathrm{Fe}(\mathrm{II})$ and $\mathrm{Mn}(\mathrm{II})$ was $96 \%$ and $95 \%$, respectively, and $97 \%$ and $96 \%$ after $90 \mathrm{~min}$, respectively. Therefore, the optimum contact time was selected as $60 \mathrm{~min}$ for further experiments. This result may be due to the use of vacant adsorption sites on the adsorbent surface. During the initial stage of sorption, a large number of vacant surface sites were available for adsorption. After a lapse in time, the remaining vacant surface sites were occupied due to repulsive forces between the solute molecules on the adsorbent surface and the bulk phase [32].

3.4. Effect of Adsorbent Dose. The study on the effect of adsorbent dose is necessary and very useful in order to find out the optimum amount of RHA required for the removal of $\mathrm{Fe}(\mathrm{II})$ and $\mathrm{Mn}$ (II) ions. Figure 4 shows the effect of the adsorbent dose on biosorption of $\mathrm{Fe}(\mathrm{II})$ and $\mathrm{Mn}$ (II) ions. The biosorption efficiency of $\mathrm{Fe}(\mathrm{II})$ and $\mathrm{Mn}$ (II) was found to increase exponentially with the increase of adsorbent dose up to 6 and $10 \mathrm{~g} / \mathrm{L}$, respectively. This may be due to the increase in availability of surface active sites resulting from the increased dose of adsorbent. At maximum biosorption, $96 \%$ for $\mathrm{Fe}(\mathrm{II})$ and $95 \%$ for $\mathrm{Mn}(\mathrm{II})$, and at higher dosages, 12 and $15 \mathrm{~g} / \mathrm{L}$, biosorption was almost the same. This result can be explained as when the adsorption dose reached a certain rate, the adsorption site was used up, hence with reduced tendency of the particles to absorb any more ions to its surface, so removal rate of heavy metal ions no longer increased [33].

3.5. Effect of $\mathrm{Fe}(\mathrm{II})$ and $\mathrm{Mn}$ (II) Ions Concentrations. The effect of initial concentrations on the removal of $\mathrm{Fe}$ (II) and $\mathrm{Mn}$ (II) ions by RHA was studied and the result is given in Figure 5 . The percentage removal was found to decrease exponentially with the increase in initial concentration of $\mathrm{Fe}$ (II) and $\mathrm{Mn}$ (II). As initial concentration of $\mathrm{Fe}(\mathrm{II})$ and $\mathrm{Mn}$ (II) increased from

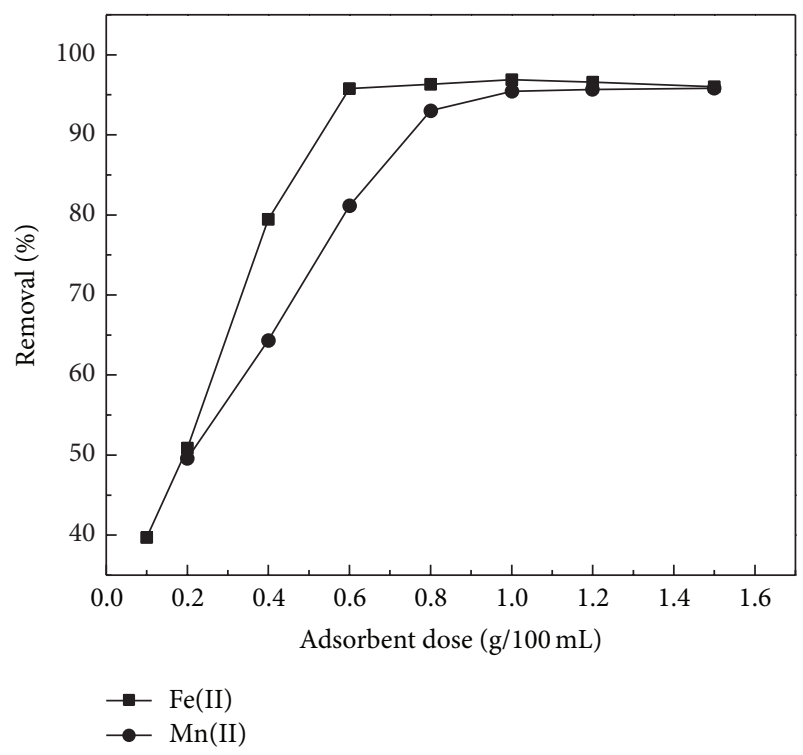

FIgURE 4: Effect of adsorbent dose on the adsorption of Fe(II) and $\mathrm{Mn}$ (II) by RHA (metal concentration: $20 \mathrm{mg} / \mathrm{L}$; contact time: 60 min; pH: 5 and 6, resp.).

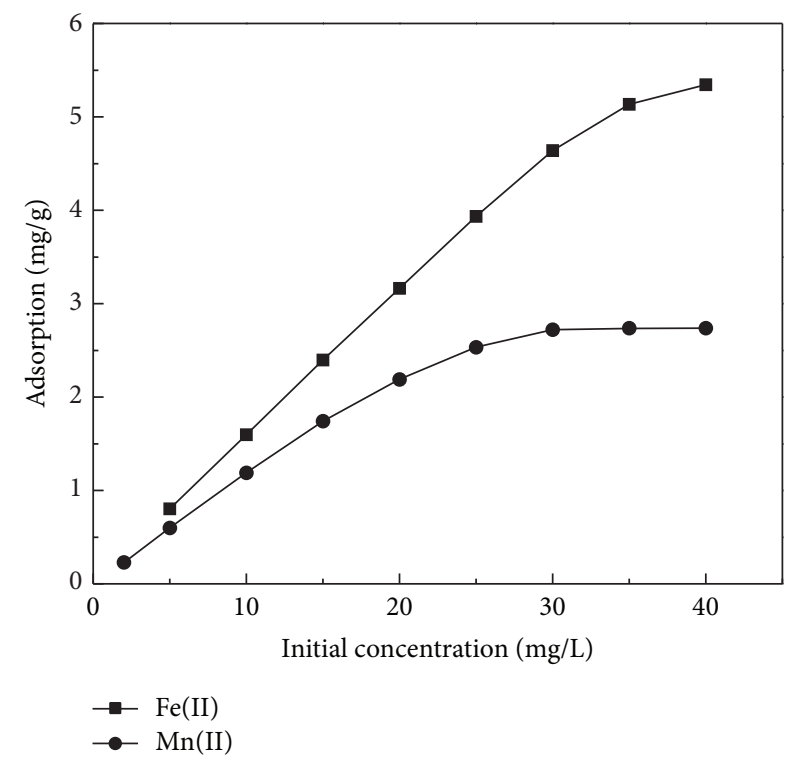

FIGURE 5: Effect of initial concentration on the Fe(II) and $\mathrm{Mn}$ (II) adsorption (adsorbent dosage: $0.6 \mathrm{~g} / 100 \mathrm{~mL}$; contact time: $60 \mathrm{~min}$; pH: 5 and 6, resp.).

5 to $40 \mathrm{mg} / \mathrm{L}$, percentage removal decreased from $96 \%$ to $80 \%$ and $90 \%$ to $55 \%$, respectively. This may be due to the lack of available active sites required for the high initial concentration of $\mathrm{Fe}(\mathrm{II})$ and $\mathrm{Mn}$ (II). Similar results have been reported in previous studies $[34,35]$.

3.6. Adsorption Kinetics. Adsorption kinetics, which is one of the important characteristics defining the adsorption efficiency of the surface of the adsorbent, describes the solute uptake rate. The kinetics of $\mathrm{Fe}(\mathrm{II})$ and $\mathrm{Mn}$ (II) adsorption was 


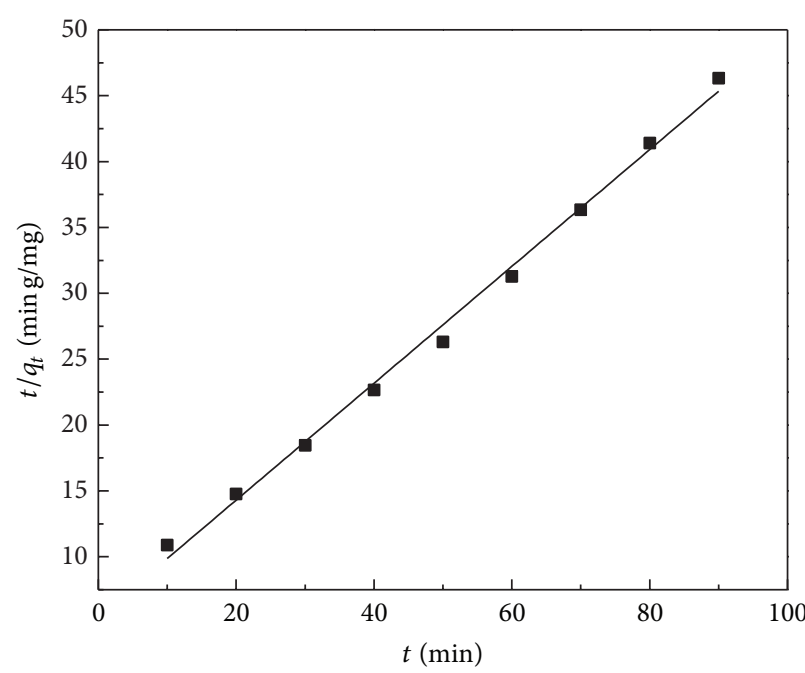

(a)

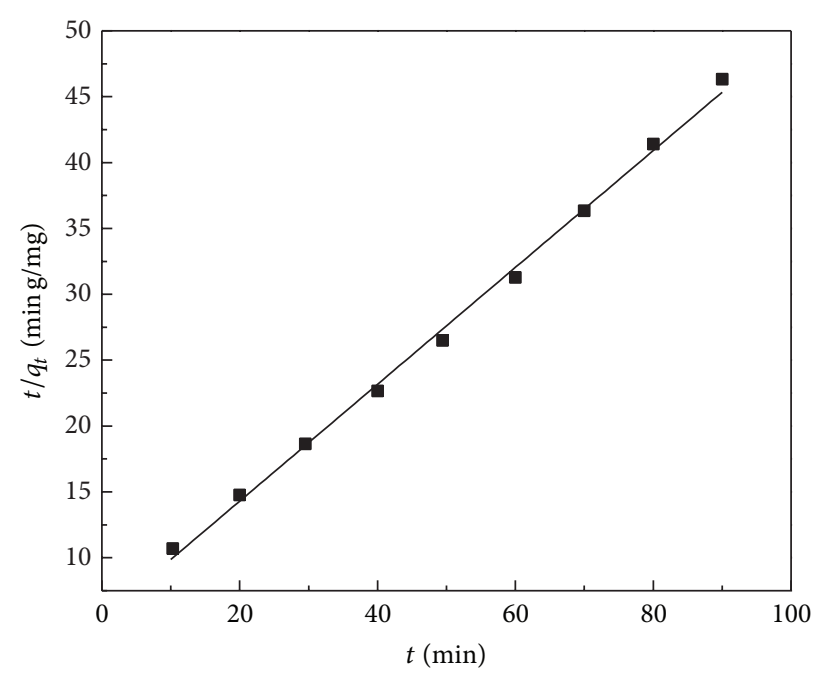

(b)

Figure 6: Pseudo-second-order kinetic plots onto RHA: (a) for Fe(II) biosorption and (b) for Mn(II) biosorption (metal concentration: $20 \mathrm{mg} / \mathrm{L}$; adsorbent dosage: $0.6 \mathrm{~g} / 100 \mathrm{~mL}$; contact time: $90 \mathrm{~min}$; $\mathrm{pH}: 5$ and 6, resp.).

TABLE 2: Kinetic parameters obtained from pseudo-first-order and pseudo-second-order for the Fe(II) and Mn(II) adsorption onto RHA.

\begin{tabular}{lcccccc}
\hline & $q_{e, \text { exp }}(\mathrm{mg} / \mathrm{g})$ & $K_{1}\left(\mathrm{~min}^{-1}\right)$ & $q_{e, \text { calc }}(\mathrm{mg} / \mathrm{g})$ & $R^{2}$ & $K_{2}(\mathrm{~g} / \mathrm{mg} \cdot \mathrm{min})$ & $q_{e, \text { calc }}(\mathrm{mg} / \mathrm{g})$ \\
\hline $\mathrm{Fe}(\mathrm{II})$ & 1.943 & 0.0714 & 2.2182 & 0.981 & 0.0361 & $R^{2}$ \\
$\mathrm{Mn}(\mathrm{II})$ & 1.936 & 0.0691 & 2.4717 & 0.974 & 0.0344 & 0.995 \\
\hline
\end{tabular}

evaluated by applying two common models: (1) the pseudofirst-order kinetic model [36] and (2) the pseudo-secondorder kinetic model [37].

The pseudo-first-order kinetic model assumes that the uptake rate of $\mathrm{Fe}(\mathrm{II})$ and $\mathrm{Mn}$ (II) with time is directly proportional to the amount of available active sites on the adsorbent surface. The pseudo-first-order kinetic model equation is given as

$$
\ln \left(q_{e}-q_{t}\right)=\ln q_{e}-k_{1} t
$$

where $q_{e}$ and $q_{t}$ are the uptake amount $(\mathrm{mg} / \mathrm{g})$ at equilibrium and $t$ (time), respectively, and $k_{1}$ is the pseudo-first-order adsorption rate constant $\left(\mathrm{min}^{-1}\right)$. The biosorption rate constants $\left(k_{1}\right)$ can be determined experimentally by plotting of $\ln \left(q_{e}-q_{t}\right)$ against $t$.

The pseudo-second-order kinetic model assumes that chemical adsorption can be the rate limiting stage involving valence forces through sharing or exchange of electrons between adsorbent and adsorbate. The pseudo-second-order kinetic equation is expressed as

$$
\frac{t}{q_{t}}=\frac{1}{K_{2} q_{e}^{2}}+\frac{t}{q_{e}}
$$

where $k_{2}(\mathrm{~g} / \mathrm{mg} \mathrm{min})$ is the rate constant of the second-order equation, $q_{t}(\mathrm{mg} / \mathrm{g})$ is the amount of biosorption time $t(\mathrm{~min})$, and $q_{e}$ is the amount of biosorption equilibrium $(\mathrm{mg} / \mathrm{g})$.

Results show that the pseudo-second-order model was more appropriate for the adsorption of Fe(II) and Mn(II). The correlation coefficients of adsorption using RHA for pseudosecond-order kinetic model are both closer to unity than those for the pseudo-first-order kinetic model. The linear plots of $t / q_{t}$ against $t$ for the pseudo-second-order model for the biosorption of $\mathrm{Fe}(\mathrm{II})$ and $\mathrm{Mn}(\mathrm{II})$ ions onto RHA are shown in Figures 6(a) and 6(b), respectively. The rate constants $\left(k_{2}\right)$ and the $R^{2}$ and the $q_{e}$ values are given in Table 2. And the theoretical $q_{e}$ values of the RHA agree well with the experimental $q_{e}$ values compared with those for the pseudo-first-order kinetic model. While the theoretical $q_{e}$ values of the rice husk adsorption for the two kinetic models both agree well with the experimental $q_{e}$ values, the kinetic models fit well with the adsorption process and confirm the chemisorption of $\mathrm{Fe}(\mathrm{II})$ and $\mathrm{Mn}$ (II) onto rice husk.

3.7. Adsorption Isotherm Models. Adsorption isotherms describe the adsorption process and how adsorbates interact with a biosorbent. It is important to establish the most acceptable correlations for the batch equilibrium data for analysis and design of adsorption systems. The most frequently used models to describe the equilibrium data of adsorption are Langmuir, Freundlich, and DubininRadushkevich isotherm models. In the present work, the three models were applied in the study of adsorption isotherms of $\mathrm{Fe}(\mathrm{II})$ and $\mathrm{Mn}(\mathrm{II})$.

The Langmuir model assumes that the uptake of metal ions is monolayer sorption on a homogenous surface and 
without any interaction between adsorbed ions [38]. This model is represented by the following equation:

$$
\frac{C_{e}}{q_{e}}=\frac{C_{e}}{q_{m}}+\frac{1}{K_{L} q_{m}},
$$

where $C_{e}$ is the equilibrium concentration of $\mathrm{Fe}(\mathrm{II})$ and $\mathrm{Mn}(\mathrm{II})$ in solutions $(\mathrm{mg} / \mathrm{L}), q_{e}$ is the equilibrium concentration of $\mathrm{Fe}(\mathrm{II})$ and $\mathrm{Mn}(\mathrm{II})$ on the biosorbent $(\mathrm{mg} / \mathrm{g}), q_{m}$ is the monolayer biosorption capacity of the biosorbent $(\mathrm{mg} / \mathrm{g})$, and $K_{L}$ is the Langmuir biosorption constant $(\mathrm{L} / \mathrm{mg})$.

Feasibility of the Langmuir isotherm in terms of a dimensionless constant was expressed by separation factor or equilibrium parameter, $R_{L}$ [39]. The equation is expressed as follows:

$$
R_{L}=\frac{1}{1+K_{L} C_{0}} .
$$

The Freundlich model assumes a heterogeneous adsorption surface and active sites with different energy [40]. Freundlich model is represented by the following equation:

$$
q_{e}=K_{F} C e^{1 / n} .
$$

The linearized logarithmic form of the equation is

$$
\log q_{e}=\log K_{F}+\frac{1}{n} \log C_{e}
$$

where $K_{F}$ is the Freundlich constant of the relative adsorption capacity of the adsorbent and the empirical parameter $1 / n$ indicates the adsorption intensity.

Smaller value of $1 / n$ implies stronger interaction between the adsorbent and heavy metal, while $1 / n$ values exist between 0 and 1 indicating the identical adsorption process and adsorption energies for all sites [41].

Figure 7 shows the nonlinear Freundlich isotherms which were obtained by plotting $\log q_{e}$ against $\log C_{e}$ values. From these plots the values of the $R^{2}$ were found to be 0.901 for $\mathrm{Fe}$ (II) biosorption and 0.892 for $\mathrm{Mn}$ (II) biosorption. However, the Langmuir isotherm was obtained by plotting $C_{e} / q_{e}$ against $C_{e}$ values, and the correlation coefficients $\left(R^{2}\right)$ were 0.995 and 0.986 for $\mathrm{Fe}(\mathrm{II})$ and $\mathrm{Mn}$ (II), respectively (Figure 8). These results indicate that the Freundlich model was not adequate to describe the relationship between the amounts of adsorbed metal ions and their equilibrium concentration in the solution. Therefore, the result showed that the Langmuir isotherm model fitted well with the equilibrium data as it presents higher $R^{2}$ values. The parameters of $\mathrm{Fe}(\mathrm{II})$ and $\mathrm{Mn}$ (II) adsorption isotherms for RHA are shown in Table 3. For favorable adsorption the value of $R_{L}$ should range in between 0 and 1 . The $R_{L}$ values for the adsorption process were estimated at initial concentration from 5 to $40 \mathrm{mg} / \mathrm{L}$ of $\mathrm{Fe}(\mathrm{II})$ and $\mathrm{Mn}$ (II) ions. For all the experimental data, these values are lying between 0 and 1 and indicated favorable adsorption [42]. The $R_{L}$ values of $\mathrm{Fe}(\mathrm{II})$ and $\mathrm{Mn}(\mathrm{II})$ in Langmuir isotherm are shown in Table 4.

Sorption energy was calculated by the D-R isotherm model to determine the nature of biosorption processes as

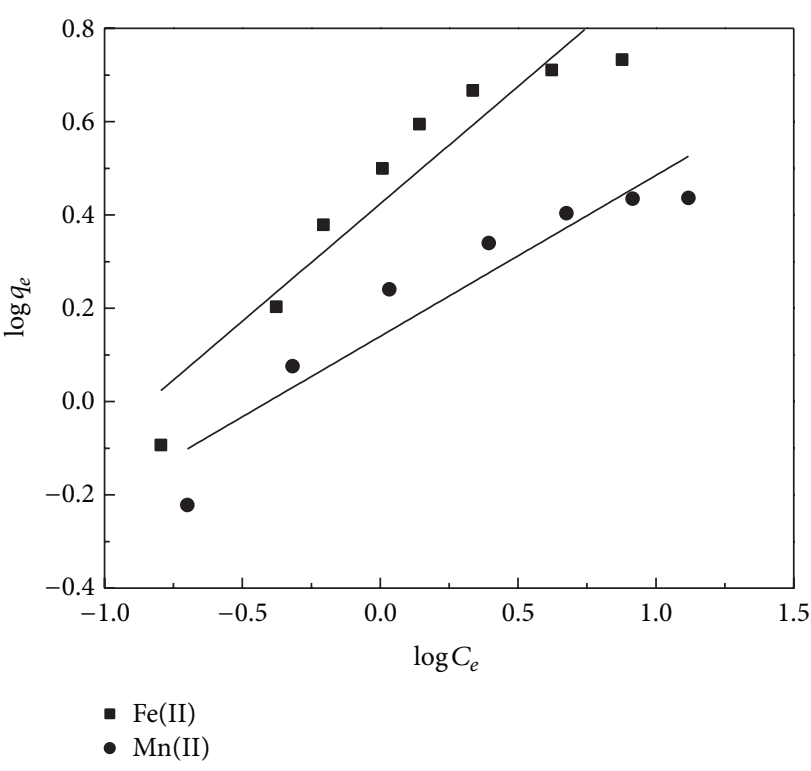

FIGURE 7: Freundlich isotherm plots for the biosorption of Fe(II) and $\mathrm{Mn}(\mathrm{II})$ onto RHA (adsorbent dosage: $0.6 \mathrm{~g} / 100 \mathrm{~mL}$; contact time: 90 min; $\mathrm{pH}$ : 5 and 6, resp.).

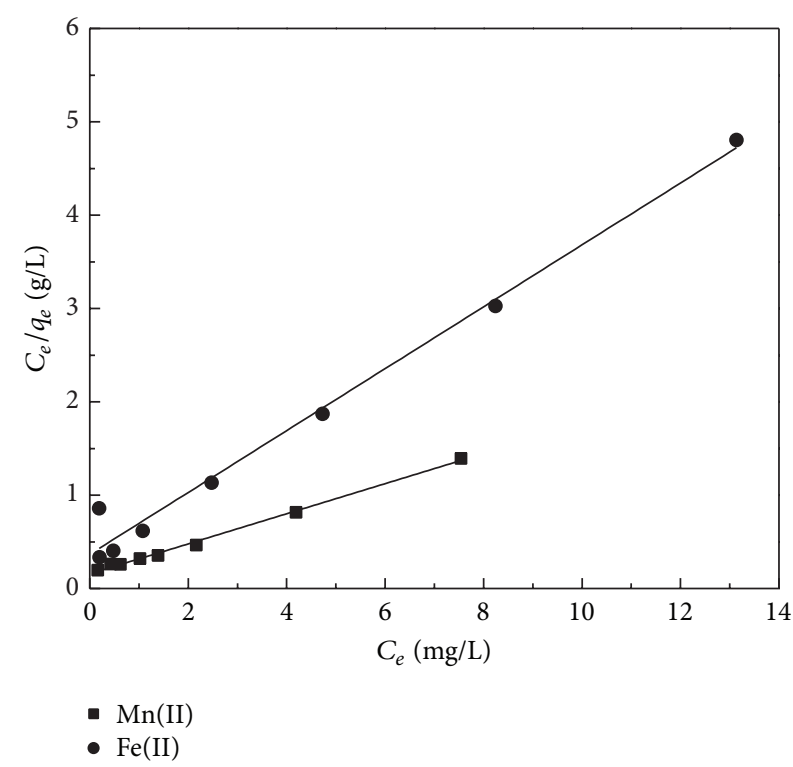

FIGURE 8: Langmuir isotherm plots for the biosorption of Fe(II) and $\mathrm{Mn}(\mathrm{II})$ onto RHA (adsorbent dosage: $0.6 \mathrm{~g} / 100 \mathrm{~mL}$; contact time: 90 min; $\mathrm{pH}: 5$ and 6, resp.).

physical or chemical. The linear presentation of the D-R isotherm equation [43] is expressed as follows:

$$
\ln q_{e}=\ln q_{m}-\beta \varepsilon^{2}
$$

where $q_{e}$ is the amount of metal ions adsorbed on per unit weight of biomass (mol/L), $q_{m}$ is the maximum biosorption capacity $(\mathrm{mol} / \mathrm{g}), \beta$ is the activity coefficient related to 
TABLE 3: Isotherm parameters for the adsorption of $\mathrm{Fe}(\mathrm{II})$ and $\mathrm{Mn}$ (II) on the RHA.

\begin{tabular}{|c|c|c|c|c|c|c|c|c|c|}
\hline & \multicolumn{3}{|c|}{ Freundlich isotherm model } & \multicolumn{3}{|c|}{ Langmuir isotherm model } & \multicolumn{3}{|c|}{$\mathrm{D}-\mathrm{R}$ isotherm model } \\
\hline & $K_{F}$ & $1 / n$ & $R^{2}$ & $K_{L}(\mathrm{~L} / \mathrm{mg})$ & $q_{m}(\mathrm{mg} / \mathrm{g})$ & $R^{2}$ & $E(\mathrm{~kJ} / \mathrm{mol})$ & $q_{m}(\mathrm{mg} / \mathrm{g})$ & $R^{2}$ \\
\hline $\mathrm{Fe}(\mathrm{II})$ & 2.649 & 0.503 & 0.901 & 1.032 & 6.211 & 0.995 & 2.53 & 4.49 & 0.917 \\
\hline $\mathrm{Mn}(\mathrm{II})$ & 1.379 & 0.345 & 0.892 & 0.907 & 3.016 & 0.986 & 2.27 & 2.54 & 0.918 \\
\hline
\end{tabular}

TABle 4: The $R_{L}$ value of Fe(II) and Mn(II) in Langmuir isotherm.

\begin{tabular}{lcccccrrr}
\hline $\begin{array}{l}\text { Different initial concentration } \\
(\mathrm{mg} / \mathrm{L})\end{array}$ & 2 & 5 & 10 & 20 & 25 & 30 & 35 & 40 \\
\hline$R_{L}$ value of $\mathrm{Fe}(\mathrm{II})$ & 0.3264 & 0.1623 & 0.0883 & 0.0462 & 0.0373 & 0.0313 & 0.0269 & 0.0237 \\
$R_{L}$ value of $\mathrm{Mn}(\mathrm{II})$ & 0.3554 & 0.1807 & 0.0993 & 0.0522 & 0.0422 & 0.0354 & 0.0305 & 0.0268 \\
\hline
\end{tabular}

TABLE 5: Comparison of maximum adsorption capacities of different adsorbents for Fe(II) and Mn(II) ions.

\begin{tabular}{|c|c|c|c|c|c|c|c|c|}
\hline & $\begin{array}{c}\text { Serial } \\
\text { no. }\end{array}$ & Adsorbents & $\begin{array}{c}\text { Adsorption } \\
\text { capacity }(\mathrm{mg} / \mathrm{g})\end{array}$ & $\begin{array}{l}\text { Contact time } \\
(\min )\end{array}$ & $\begin{array}{c}\text { Concentration } \\
\text { range }(\mathrm{mg} / \mathrm{L})\end{array}$ & $\mathrm{pH}$ & $\begin{array}{l}\text { Temp. range } \\
(\mathrm{K})\end{array}$ & References \\
\hline \multirow{8}{*}{$\mathrm{Fe}(\mathrm{II})$} & 1 & Coir fibres & 2.84 & 120 & $73.50-83.9$ & 5 & 308 & {$[48]$} \\
\hline & 2 & Modified coir fibres & 7.49 & 120 & $73.50-83.9$ & 5 & 308 & {$[48]$} \\
\hline & 3 & $\begin{array}{l}\text { Activated carbon from } \\
\text { coconut shells }\end{array}$ & 81.89 & 90 & $20-100$ & 6 & 298 & {$[10]$} \\
\hline & 4 & $\begin{array}{l}\text { Chitosan/polyethylene glycol } \\
\text { blend membrane }\end{array}$ & 90.9 & 80 & $2-10$ & 5 & 300 & {$[49]$} \\
\hline & 5 & Pine bark wastes & 2.03 & 30 & $55.6-111.2$ & 4 & $303-333$ & {$[50]$} \\
\hline & 6 & Chitosan & 57.5 & 40 & $3-9$ & 5 & - & {$[51]$} \\
\hline & 7 & Cross-linked chitosan & 64.1 & 60 & $3-9$ & 5 & - & {$[51]$} \\
\hline & 8 & Rice husk ash & 6.21 & 60 & $2-40$ & 5 & 298 & Present study \\
\hline \multirow{12}{*}{$\mathrm{Mn}(\mathrm{II})$} & 9 & Pithecellobium dulce carbon & 7.0 & 50 & $5-25$ & 7 & - & {$[34]$} \\
\hline & 10 & Crab shell particles & 69.9 & 120 & $10-1000$ & 6 & 296 & {$[52]$} \\
\hline & 11 & Bombax malabaricum & 8.2 & 50 & $5-25$ & 7 & - & {$[35]$} \\
\hline & 12 & Pithecellobium dulce & 7.0 & 90 & $5-25$ & 9 & - & {$[35]$} \\
\hline & 13 & Ipomea batatas & 6.0 & 90 & $5-25$ & 9 & - & {$[35]$} \\
\hline & 14 & Peltophorum ferrugineum & 5.5 & 90 & $5-25$ & 7 & - & {$[35]$} \\
\hline & 15 & Activated zeolite with $\mathrm{NaCl}$ & 0.78 & 150 & $5-600$ & 6 & 298 & {$[30]$} \\
\hline & 16 & $\begin{array}{l}\text { Manganese oxide coated } \\
\text { zeolite }\end{array}$ & 1.1 & 150 & $25-600$ & 6 & 298 & {$[53]$} \\
\hline & 17 & $\begin{array}{l}\text { Chitosan/polyethylene glycol } \\
\text { blend membrane }\end{array}$ & 21.7 & 80 & $2-10$ & 6 & 300 & {$[48]$} \\
\hline & 18 & $\begin{array}{l}\text { Activated carbon from } \\
\text { coconut shells }\end{array}$ & 75.65 & 90 & $20-100$ & 7 & 298 & {$[10]$} \\
\hline & 19 & $\begin{array}{l}\text { Tannic acid immobilised } \\
\text { activated carbon }\end{array}$ & 1.13 & 60 & $1-10$ & 7 & 298 & {$[54]$} \\
\hline & 20 & Rice husk ash & 3.02 & 60 & $2-40$ & 6 & 298 & Present study \\
\hline
\end{tabular}

biosorption mean free energy $\left(\mathrm{mol}^{2} / \mathrm{J}^{2}\right), \varepsilon$ is the Polanyi potential [44], and the equation is given as

$$
\varepsilon=\mathrm{RT} \ln \left(1+\frac{1}{C_{e}}\right) .
$$

The biosorption mean free energy $(E ; \mathrm{kJ} / \mathrm{mol})$ is described as

$$
E=\frac{1}{\sqrt{-2 \beta}} .
$$

The biosorption mean free energy gives information about biosorption mechanism. If $E$ value is between 8 and $16 \mathrm{~kJ} / \mathrm{mol}$, the biosorption process was chemical ion exchange in nature and if $E<8 \mathrm{~kJ} / \mathrm{mol}$, it was physical in nature $[45,46]$. The mean biosorption energy was calculated as 2.53 and $2.27 \mathrm{~kJ} / \mathrm{mol}$ for the biosorption of $\mathrm{Fe}(\mathrm{II})$ and $\mathrm{Mn}$ (II) ions, respectively (Table 3 ). These results suggest that the biosorption processes of both metal ions onto RHA were physical in nature because the sorption energies were less than $8 \mathrm{~kJ} / \mathrm{mol}$. 
3.8. Comparison Study. Table 5 gives the maximum capacities of different adsorbents for the removal of $\mathrm{Fe}$ (II) and $\mathrm{Mn}$ (II) from aqueous solutions. It can be seen that maximum adsorptive capacities for these metal ions were different for different materials used. This will depend on the physical nature and chemical composition of the materials used from removal of metal ions. It can be seen from the table that rice husk ash has comparable adsorption capacity with respect to other adsorbents reported in the literature [47].

\section{Conclusions}

This study focused on the biosorption of Fe(II) and Mn(II) ions onto RHA from aqueous solution. The operating parameters, $\mathrm{pH}$ of the solution, contact time, adsorbent dosage, and initial concentration, were effective on the biosorption efficiency of $\mathrm{Fe}(\mathrm{II})$ and $\mathrm{Mn}$ (II). The maximum biosorption capacity $\left(q_{m}\right)$ of RHA was found to be $6.211 \mathrm{mg} / \mathrm{g}$ for Fe(II) ions and $3.016 \mathrm{mg} / \mathrm{g}$ for $\mathrm{Mn}$ (II) ions. The equilibrium adsorption experiments fitted well with Langmuir than Freundlich isotherm models and showed a correlation coefficient $R^{2}$ equals 0.995 and 0.986 , respectively. The mean free energy values evaluated from the $\mathrm{D}-\mathrm{R}$ model indicated that the biosorption of $\mathrm{Fe}$ (II) and $\mathrm{Mn}$ (II) onto RHA has taken place by physical sorption in nature. The equilibrium data indicated that the biosorption of $\mathrm{Fe}(\mathrm{II})$ and $\mathrm{Mn}$ (II) ions onto RHA followed well the pseudo-second-order kinetic model. It can also be concluded that the RHA is an effective and alternative material for the removal of $\mathrm{Fe}$ (II) and $\mathrm{Mn}$ (II) ions from wastewater because of its high biosorption capacity, costeffectiveness, and abundant availability.

\section{Conflict of Interests}

All authors declared that there is no conflict of interests regarding the publication of this paper.

\section{Acknowledgments}

This paper is supported by the National Natural Science Foundation of China (no. 41101526), the National Scientific and Technological Supporting Project, China (2013BAJ12B01), and the University Science and Technology Innovation Team Construction Projects of Heilongjiang Province (2013TD003).

\section{References}

[1] C. Namasivayam and M. V. Sureshkumar, "Removal of chromium(VI) from water and wastewater using surfactant modified coconut coir pith as a biosorbent," Bioresource Technology, vol. 99, no. 7, pp. 2218-2225, 2008.

[2] R. J. E. Martins, R. Pardo, and R. A. R. Boaventura, "Cadmium(II) and zinc(II) adsorption by the aquatic moss Fontinalis antipyretica: effect of temperature, $\mathrm{pH}$ and water hardness," Water Research, vol. 38, no. 3, pp. 693-699, 2004.

[3] R. A. Gil, M. M. Kaplan, J. A. Salonia, J. A. Gásquez, and L. D. Martinez, "Total inorganic Se and Te preconcentration and their determination by on-line coupling of a solid-phase extraction procedure with HG-AAS," Atomic Spectroscopy, vol. 28, no. 2, pp. 67-72, 2007.

[4] D. Rekha, K. Suvardhan, K. S. Kumar, P. Reddyprasad, B. Jayaraj, and P. Chiranjeevi, "Extractive spectrophotometric determination of copper(II) in water and alloy samples with 3methoxy-4-hydroxy benzaldehyde-4-bromophenyl hydrazone (3,4-MHВBРH)," Journal of the Serbian Chemical Society, vol. 72, no. 3, pp. 299-310, 2007.

[5] J. L. Lin, C. Huang, J. R. Pan, and Y.-S. Wang, "Fouling mitigation of a dead-end microfiltration by mixing-enhanced preoxidation for Fe and Mn removal from groundwater," Colloids and Surfaces A: Physicochemical and Engineering Aspects, vol. 419, pp. 87-93, 2013.

[6] R. El Araby, S. Hawash, and G. El Diwani, "Treatment of iron and manganese in simulated groundwater via ozone technology," Desalination, vol. 249, no. 3, pp. 1345-1349, 2009.

[7] A. bin Jusoh, W. H. Cheng, W. M. Low, A. Nora'aini, and M. J. Megat Mohd Noor, "Study on the removal of iron and manganese in groundwater by granular activated carbon," Desalination, vol. 182, no. 1-3, pp. 347-353, 2005.

[8] F. R. Spellman, Handbook For Waterworks Operator Certification ,, vol. 2, Technomic Publishing Company Inc., Lancaster, $\mathrm{Pa}$, USA, 2001.

[9] R. E. R. Machmeier, "Iron and Drinking Water," AG-FO. 1318, University of Minnesota, Agriculture, 1990.

[10] J. C. Moreno-Piraján, V. S. Garcia-Cuello, and L. Giraldo, "The removal and kinetic study of $\mathrm{Mn}, \mathrm{Fe}, \mathrm{Ni}$ and $\mathrm{Cu}$ ions from wastewater onto activated carbon from coconut shells," Adsorption, vol. 17, no. 3, pp. 505-514, 2011.

[11] J. A. S. Tenório and D. C. R. Espinosa, “Treatment of chromium plating process effluents with ion exchange resins," Waste Management, vol. 21, no. 7, pp. 637-642, 2001.

[12] J. O. Esalah, M. E. Weber, and J. H. Vera, "Removal of lead, cadmium and zinc from aqueous solutions by precipitation with sodium di-(n-octyl) phosphinate," Canadian Journal of Chemical Engineering, vol. 78, no. 5, pp. 948-954, 2000.

[13] S. Hirata, K. Honda, and T. Kumamaru, "Trace metal enrichment by automated on-line column preconcentration for flowinjection atomic absorption spectrometry," Analytica Chimica Acta, vol. 221, pp. 65-76, 1989.

[14] D. Buerge-Weirich, R. Hari, H. Xue, P. Behra, and L. Sigg, "Adsorption of $\mathrm{Cu}, \mathrm{Cd}$, and $\mathrm{Ni}$ on goethite in the presence of natural groundwater ligands," Environmental Science and Technology, vol. 36, no. 3, pp. 328-336, 2002.

[15] G. Yan and T. Viraraghavan, "Heavy metal removal in a biosorption column by immobilized M. rouxii biomass," Bioresource Technology, vol. 78, no. 3, pp. 243-249, 2001.

[16] M. A. Hanif, R. Nadeem, H. N. Bhatti, N. R. Ahmad, and T. M. Ansari, "Ni(II) biosorption by Cassia fistula (Golden Shower) biomass," Journal of Hazardous Materials, vol. 139, no. 2, pp. 345-355, 2007.

[17] A. K. Bhattacharya, T. K. Naiya, S. N. Mandal, and S. K. Das, "Adsorption, kinetics and equilibrium studies on removal of $\mathrm{Cr}(\mathrm{VI})$ from aqueous solutions using different low-cost adsorbents," Chemical Engineering Journal, vol. 137, no. 3, pp. 529-541, 2008.

[18] T. K. Naiya, A. K. Bhattacharya, and S. K. Das, "Removal of $\mathrm{Cd}(\mathrm{II})$ from aqueous solutions using clarified sludge," Journal of Colloid and Interface Science, vol. 325, no. 1, pp. 48-56, 2008.

[19] T. S. Anirudhan and S. S. Sreekumari, "Adsorptive removal of heavy metal ions from industrial effluents using activated 
carbon derived from waste coconut buttons," Journal of Environmental Sciences, vol. 23, no. 12, pp. 1989-1998, 2011.

[20] M. A. A. Zaini, Y. Amano, and M. Machida, "Adsorption of heavy metals onto activated carbons derived from polyacrylonitrile fiber," Journal of Hazardous Materials, vol. 180, no. 1-3, pp. 552-560, 2010.

[21] H. Modin, K. M. Persson, A. Andersson, and M. van Praagh, "Removal of metals from landfill leachate by sorption to activated carbon, bone meal and iron fines," Journal of Hazardous Materials, vol. 189, no. 3, pp. 749-754, 2011.

[22] S. Mohan and R. Gandhimathi, "Removal of heavy metal ions from municipal solid waste leachate using coal fly ash as an adsorbent," Journal of Hazardous Materials, vol. 169, no. 1-3, pp. 351-359, 2009.

[23] E. Erdem, N. Karapinar, and R. Donat, "The removal of heavy metal cations by natural zeolites," Journal of Colloid and Interface Science, vol. 280, no. 2, pp. 309-314, 2004.

[24] Y. Bulut and Z. Baysal, "Removal of $\mathrm{Pb}$ (II) from wastewater using wheat bran," Journal of Environmental Management, vol. 78, no. 2, pp. 107-113, 2006.

[25] V. Marchetti, A. Clément, P. Gérardin, and B. Loubinoux, "Synthesis and use of esterified sawdusts bearing carboxyl group for removal of cadmium(II) from water," Wood Science and Technology, vol. 34, no. 2, pp. 167-173, 2000.

[26] K. Wilson, H. Yang, C. W. Seo, and W. E. Marshall, "Select metal adsorption by activated carbon made from peanut shells," Bioresource Technology, vol. 97, no. 18, pp. 2266-2270, 2006.

[27] E. I. El-Shafey, "Removal of $\mathrm{Zn}(\mathrm{II})$ and $\mathrm{Hg}$ (II) from aqueous solution on a carbonaceous sorbent chemically prepared from rice husk," Journal of Hazardous Materials, vol. 175, no. 1-3, pp. 319-327, 2010.

[28] U. R. Lakshmi, V. C. Srivastava, I. D. Mall, and D. H. Lataye, "Rice husk ash as an effective adsorbent: evaluation of adsorptive characteristics for Indigo Carmine dye," Journal of Environmental Management, vol. 90, no. 2, pp. 710-720, 2009.

[29] V. C. Srivastava, M. M. Swamy, I. D. Mall, B. Prasad, and I. M. Mishra, "Adsorptive removal of phenol by bagasse fly ash and activated carbon: equilibrium, kinetics and thermodynamics," Colloids and Surfaces A: Physicochemical and Engineering Aspects, vol. 272, no. 1-2, pp. 89-104, 2006.

[30] S. R. Taffarel and J. Rubio, "On the removal of $\mathrm{Mn}^{2+}$ ions by adsorption onto natural and activated Chilean zeolites," Minerals Engineering, vol. 22, no. 4, pp. 336-343, 2009.

[31] T. Akar and S. Tunali, "Biosorption performance of Botrytis cinerea fungal by-products for removal of $\mathrm{Cd}(\mathrm{II})$ and $\mathrm{Cu}(\mathrm{II})$ ions from aqueous solutions," Minerals Engineering, vol. 18, no. 11, pp. 1099-1109, 2005.

[32] J. Wongjunda and P. Saueprasearsit, "Biosorption of chromiumm(VI) using RHA and modified RHA," Environmental Research Journal, vol. 4, pp. 244-250, 2010.

[33] Y. B. Onundi, A. A. Mamun, M. F. Al Khatib, and Y. M. Ahmed, "Adsorption of copper, nickel and lead ions from synthetic semiconductor industrial wastewater by palm shell activated carbon," International Journal of Environmental Science and Technology, vol. 7, no. 4, pp. 751-758, 2010.

[34] K. A. Emmanuel and A. V. Rao, "Adsorption of Mn (II) from aqueous solutions using pithacelobium dulce carbon," Rasayan Journal of Chemistry, vol. 1, pp. 840-852, 2008.

[35] K. A. Emmanuel and A. V. Rao, "Comparative study on adsorption of $\mathrm{Mn}$ (II) from aqueous solutions on various activated carbons," Journal of Chemistry, vol. 6, no. 3, pp. 693-704, 2009.
[36] K. G. Bhattacharyya and A. Sharma, "Azadirachta indica leaf powder as an effective biosorbent for dyes: a case study with aqueous Congo Red solutions," Journal of Environmental Management, vol. 71, no. 3, pp. 217-229, 2004.

[37] Y. S. Ho and G. McKay, "Pseudo-second order model for sorption processes," Process Biochemistry, vol. 34, no. 5, pp. 451465, 1999.

[38] I. Langmuir, "The adsorption of gases on plane surfaces of glass, mica and platinum," The Journal of the American Chemical Society, vol. 40, no. 9, pp. 1361-1403, 1918.

[39] T. W. Weber and R. K. Chakravorti, "Pore and solid diffusion models for fixed bed adsorbers," AIChE Journal, vol. 20, no. 2, pp. 228-238, 1974.

[40] H. Freundlich, “Uber die adsorption in losungen," Zeitschrift für Physikalische Chemie, vol. 57, pp. 385-470, 1906.

[41] A. Delle Site, "Factors affecting sorption of organic compounds in natural sorbent/water systems and sorption coefficients for selected pollutants. A review," Journal of Physical and Chemical Reference Data, vol. 30, no. 1, pp. 187-439, 2001.

[42] B. Singha and S. K. Das, "Adsorptive removal of $\mathrm{Cu}(\mathrm{II})$ from aqueous solution and industrial effluent using natural/agricultural wastes,' Colloids and Surfaces B: Biointerfaces, vol. 107, pp. 97-106, 2013.

[43] M. M. Dubinin, E. D. Zaverina, and L. V. Radushkevich, "Sorption and structure of active carbons. I. Adsorption of organic vapors," Zhurnal Fizicheskoi Khimii, vol. 21, pp. 1351$1362,1947$.

[44] M. Polanyi, "Theories of the adsorption of gases. A general survey and some additional remarks. Introductory paper to section III," Transactions of the Faraday Society, vol. 28, pp. 316333, 1932.

[45] T. K. Naiya, A. K. Bhattacharya, S. Mandal, and S. K. Das, "The sorption of lead(II) ions on rice husk ash," Journal of Hazardous Materials, vol. 163, no. 2-3, pp. 1254-1264, 2009.

[46] M. F. Sawalha, J. R. Peralta-Videa, J. Romero-González, and J. L. Gardea-Torresdey, "Biosorption of Cd(II), Cr(III), and Cr(VI) by saltbush (Atriplex canescens) biomass: Thermodynamic and isotherm studies," Journal of Colloid and Interface Science, vol. 300, no. 1, pp. 100-104, 2006.

[47] B. Singha and S. K. Das, "Removal of $\mathrm{Pb}$ (II) ions from aqueous solution and industrial effluent using natural biosorbents," Environmental Science and Pollution Research, vol. 19, no. 6, pp. 2212-2226, 2012.

[48] S. R. Shukla, R. S. Pai, and A. D. Shendarkar, "Adsorption of $\mathrm{Ni}(\mathrm{II}), \mathrm{Zn}(\mathrm{II})$ and $\mathrm{Fe}(\mathrm{II})$ on modified coir fibres," Separation and Purification Technology, vol. 47, no. 3, pp. 141-147, 2006.

[49] N. A. Reiad, O. E. A. Salam, E. F. Abadir, and F. A. Harraz, "Adsorptive removal of iron and manganese ions from aqueous solutions with microporous chitosan/polyethylene glycol blend membrane," Journal of Environmental Sciences, vol. 24, no. 8, pp. 1425-1432, 2012.

[50] B. Acemioğlu, "Removal of Fe(II) ions from aqueous solution by Calabrian pine bark wastes," Bioresource Technology, vol. 93, no. 1, pp. 99-102, 2004.

[51] W. S. Ngah, S. Ab Ghani, and A. Kamari, "Adsorption behaviour of $\mathrm{Fe}$ (II) and $\mathrm{Fe}$ (III) ions in aqueous solution on chitosan and cross-linked chitosan beads," Bioresource Technology, vol. 96, no. 4, pp. 443-450, 2005.

[52] K. Vijayaraghavan, H. Y. N. Winnie, and R. Balasubramanian, "Biosorption characteristics of crab shell particles for the removal of manganese(II) and zinc(II) from aqueous solutions," Desalination, vol. 266, no. 1-3, pp. 195-200, 2011. 
[53] S. R. Taffarel and J. Rubio, "Removal of $\mathrm{Mn}^{2+}$ from aqueous solution by manganese oxide coated zeolite," Minerals Engineering, vol. 23, no. 14, pp. 1131-1138, 2010.

[54] A. Üçer, A. Uyanik, and Ş. F. Aygün, "Adsorption of Cu (II), Cd (II), Zn (II), Mn (II) and Fe (III) ions by tannic acid immobilised activated carbon," Separation and Purification Technology, vol. 47, pp. 113-118, 2006. 

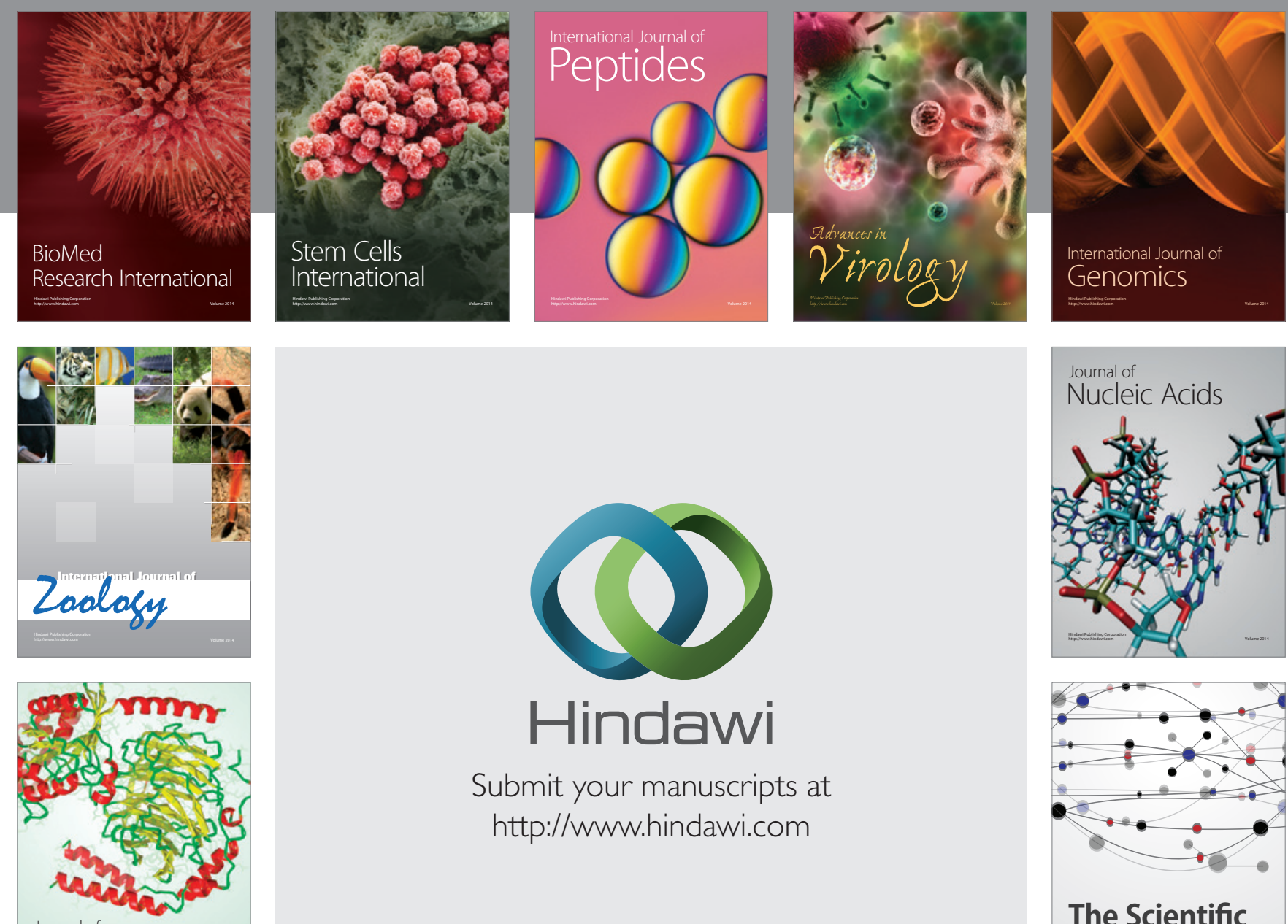

Submit your manuscripts at

http://www.hindawi.com

Journal of
Signal Transduction
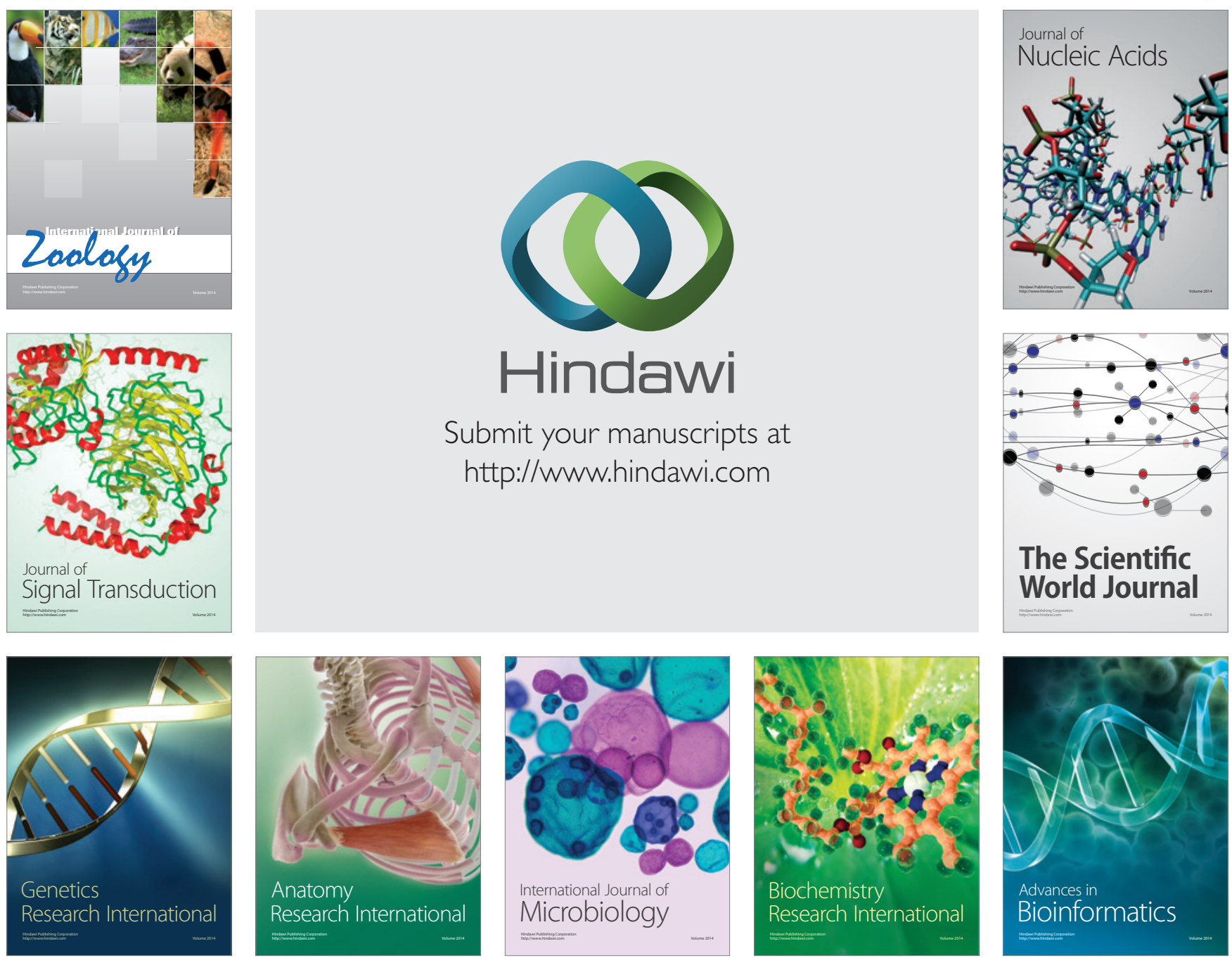

The Scientific World Journal
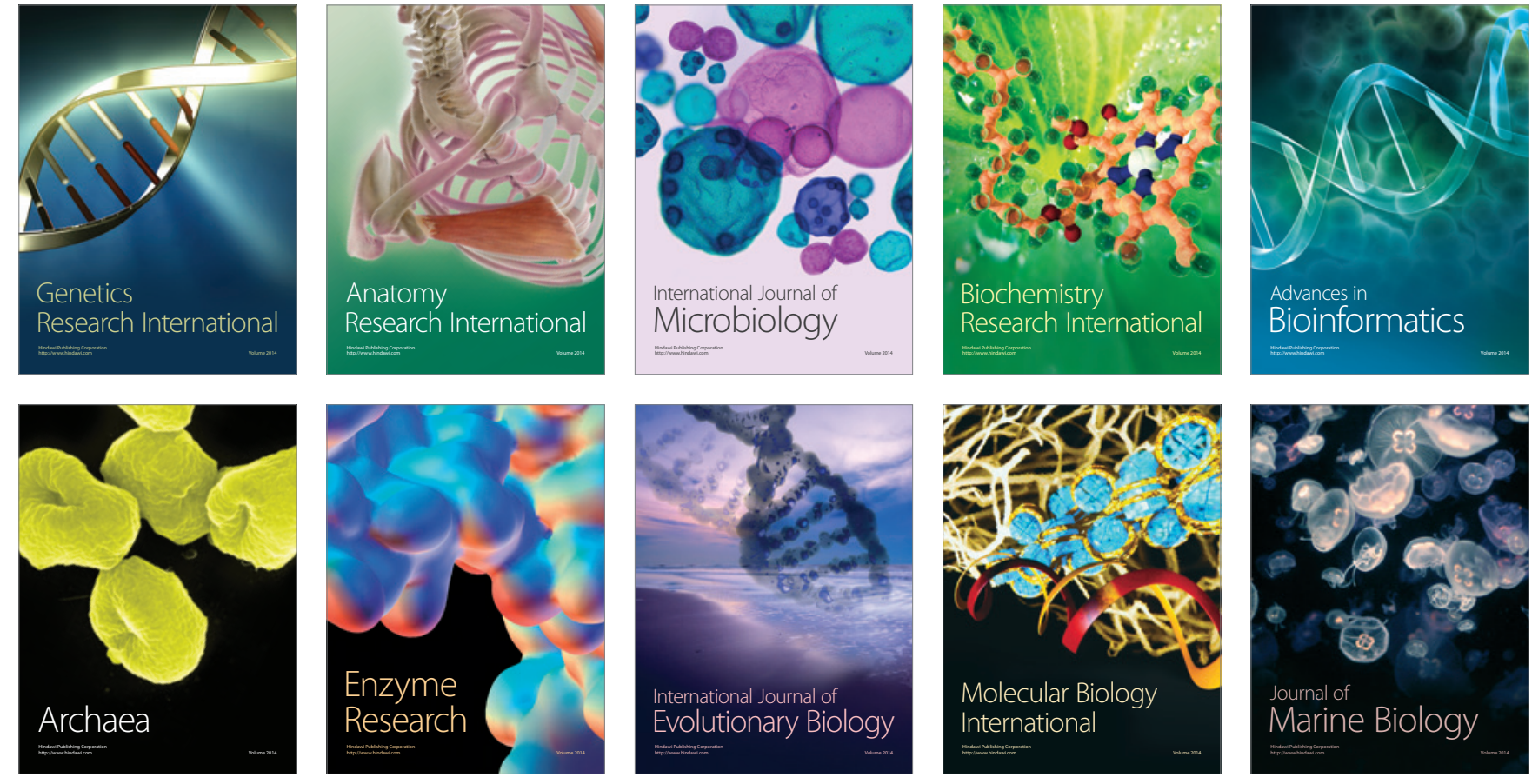